\title{
Comparison of methods for the detection and extrapolation of trends in groundwater quality
}

\author{
Ate Visser, ${ }^{* a b}$ Igor Dubus, $\dagger^{c}$ Hans Peter Broers, ${ }^{a}$ Serge Brouyère, ${ }^{d}$ Marek Korcz, ${ }^{e}$ Philippe Orban, ${ }^{d}$ \\ Pascal Goderniaux, ${ }^{d}$ Jordi Batlle-Aguilar, $\dagger^{d}$ Nicolas Surdyk, ${ }^{c}$ Nadia Amraoui, ${ }^{c}$ Hélène Job, ${ }^{c}$ \\ Jean Louis Pinault ${ }^{c}$ and Marc Bierkens ${ }^{a b}$
}

\author{
Received 31st March 2009, Accepted 3rd August 2009 \\ First published as an Advance Article on the web 7th September 2009 \\ DOI: $10.1039 / \mathrm{b} 905926 \mathrm{a}$
}

\begin{abstract}
Land use changes and the intensification of agriculture since the 1950s have resulted in a deterioration of groundwater quality in many European countries. For the protection of groundwater quality, it is necessary to (1) assess the current groundwater quality status, (2) detect changes or trends in groundwater quality, (3) assess the threat of deterioration and (4) predict future changes in groundwater quality. A variety of approaches and tools can be used to detect and extrapolate trends in groundwater quality, ranging from simple linear statistics to distributed 3D groundwater contaminant transport models. In this paper we report on a comparison of four methods for the detection and extrapolation of trends in groundwater quality: (1) statistical methods, (2) groundwater dating, (3) transfer functions, and (4) deterministic modeling. Our work shows that the selection of the method should firstly be made on the basis of the specific goals of the study (only trend detection or also extrapolation), the system under study, and the available resources. For trend detection in groundwater quality in relation to diffuse agricultural contamination, a very important aspect is whether the nature of the monitoring network and groundwater body allows the collection of samples with a distinct age or produces samples with a mixture of young and old groundwater. We conclude that there is no single optimal method to detect trends in groundwater quality across widely differing catchments.
\end{abstract}

\section{Introduction}

${ }^{a}$ Deltares/TNO - Geological Survey of the Netherlands, Division of Soil and Groundwater systems, P.O. Box 85467, 3508 AL Utrecht, The Netherlands. E-mail: ate.visser@deltares.nl; Fax: +31 30256 4855; Tel: $+31302564816$

${ }^{b}$ Utrecht University, Department of Physical Geography, P.O. Box 80115 , 3508 TC Utrecht, The Netherlands

${ }^{c} B R G M$, Water Division, BP 6009, 45060 Orléans Cedex 2, France

${ }^{d} H G-U L g$, Aquapôle, University of Liege, Building B52/3, 4000 Sart Tilman, Belgium

${ }^{e}$ Institute for Ecology of Industrial Areas, ul. Kossutha 6, 40-844 Katowice, Poland

$\dagger$ Present address: FOOTWAYS, 10 avenue Buffon, 45071 Orleans Cedex 2, France.

+ Present address: Ecological Engineering Laboratory, École Polytechnique Fédérale de Lausanne (EPFL), Station 2, Building GR, CH-1015, Lausanne, Switzerland.
Land use changes and the intensification of agriculture since the 1950s have resulted in increased pressures on natural systems. For example, the diffuse pollution of groundwater with agricultural contaminants such as nitrate and pesticides has resulted in a deterioration of groundwater quality. ${ }^{1-3}$ The surplus of nitrogen applied to agricultural land, and possibly leaching to groundwater, shows similar trends for most European countries and the United States (Fig. 1): upward until the late 1980s and stabilization or decreasing trends afterward. The transfer of these contaminants to deeper groundwater and surface water represents a major threat to the long-term sustainability of water resources across the Europe and elsewhere. ${ }^{4}$

For the protection of groundwater quality in the European Union (EU), the Water Framework Directive [WFD, ref. 5] and the Groundwater Directive [GWD, ref. 6] require member states

\section{Environmental impact}

The transfer of diffuse agricultural contaminants to deeper groundwater and surface water represents a major threat to the long-term sustainability of water resources.

To identify possible threats to future water quality, it is essential to detect sustained upward trends in the concentrations of pollutants in an early stage. Trend detection is often complicated by limited monitoring data, variations in the transport of contaminants toward monitoring locations, variations in application of contaminants in space and time, and (partial) degradation of contaminants in the subsurface. This work provides the scientific basis for choosing the method for trend detection in the framework of environmental legislation by assessing the capabilities and efficiency of various tools to detect and extrapolate trends in groundwater quality. 


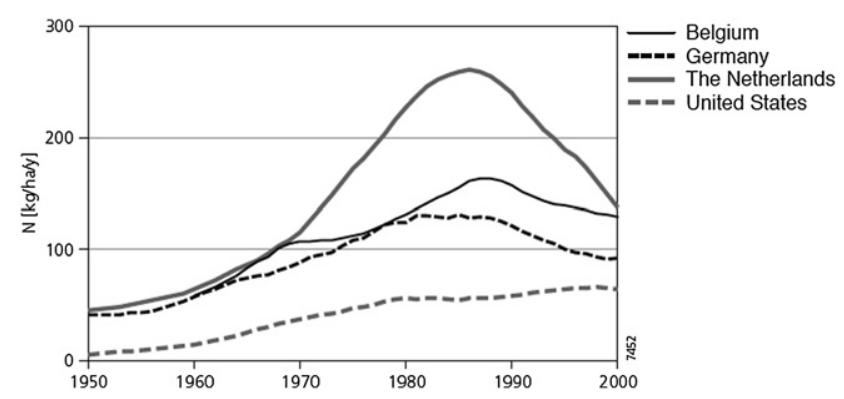

Fig. 1 Estimates of nitrogen deposition on agricultural land in Belgium (data courtesy of Gembloux Agricultural University), SchleswigHolstein, Germany (data from ref. 89), Noord-Brabant, the Netherlands (data from ref. 32), and the United States (including pasture land, data courtesy of USGS).

to achieve good chemical status of their groundwater bodies by the year 2015. To achieve this, these directives ask member states to delineate groundwater bodies and assess the present chemical status of these groundwater bodies. To detect possible threats to future groundwater quality, the GWD asks for the detection of sustained upward trends in the concentrations of pollutants. If upward trends are found, these should be reversed when the concentration of the pollutant reaches $75 \%$ of the threshold value. The GWD also lays down requirements on the implementation of measures necessary to reverse any significant and sustained upward trend. In the context of the WFD and GWD, the scientific community will be asked the following with respect to groundwater quality: (1) assess the current status, (2) detect changes or trends, (3) assess the threat of deterioration by relating these trends to historical changes in land use, and (4) predict future changes by extrapolating present day trends and possibly predict trend reversal in response to legislation.

While the WFD requires groundwater quality monitoring networks to be operational by the year 2007, the awareness of the threat to groundwater quality has already led to the installation of monitoring networks in many countries such as Korea, ${ }^{7,8}$ Denmark, ${ }^{9}$ the Netherlands, ${ }^{10}$ New Zealand, ${ }^{11}$ Palestine, ${ }^{12}$ the US, ${ }^{13,14}$ and the UK. ${ }^{15}$ These networks have since produced time series of monitoring data which have been used to detect and quantify changes in groundwater quality. ${ }^{16-23}$

These studies showed that trends in groundwater quality are difficult to detect. Most often the period of interest is longer than the period of record ${ }^{24}$ and available time series are typically rather short and sparse because of the high costs of sampling and analysis. The lack of substantial data usually limits the application of statistical methods to simple approaches rather than more complex time series analysis tools. Other factors complicating trend detection are: variations in the duration and pathways of the transport of contaminants toward monitoring location by groundwater flow, variations in application of contaminants at the ground surface, in space and time, and (partial) degradation of contaminants in the subsurface. ${ }^{20}$ Additionally, the travel time of sampled groundwater may be uncertain, in particular because the groundwater sample may represent a range of travel times. Whether the character of the groundwater flow system causes mixing of groundwater, for example in dual-porosity systems, and whether the groundwater sample contains a mixture of groundwater, for example from springs or production wells, are important factors for the success of trend detection in groundwater quality. This difference can influence the sampled concentration of nitrate, because the mixture sampled from a supply well contains a portion of old, pre-agricultural groundwater with no nitrate. ${ }^{4}$ Data from supply wells should therefore be regarded as a sampling of a different sub-population. ${ }^{25}$ In situations where samples contain groundwater with a distinct age, several studies have used groundwater age tracers to enhance the interpretation of measured concentrations of pollutants. $^{26-32}$

To assess whether an upward trend in the concentration of a contaminant will threaten groundwater quality, a variety of tools can be used to detect and extrapolate trends in groundwater quality. These range from linear statistics ${ }^{\mathbf{1 8 , 2 0 , 2 2}}$ relating trends to changing land use patterns $\mathrm{s}^{33-36}$ and predict future trends based on land use scenarios; $;^{37,38}$ trends in groundwater quality can also be predicted using empirical, functional or deterministic models of varying complexity. ${ }^{39-41}$ The efficiency of these tools depends on several factors like the availability of groundwater quality data, the character of the groundwater flow system, and the available resources for trend assessment.

To address the challenges of the WFD, a number of working groups were asked to design a common implementation strategy (CIS) and produce "guidance documents" for the implementation of the WFD. The mandate of the Groundwater Working Group (WGC) required the development of practical guidance and technical specifications for the derivation of threshold values, the assessment of status compliance (both quantitative and chemical) and the assessment of groundwater trends and trend reversal. The focus of the guidance document was on "statistical aspects of the identification of groundwater pollution trends, and aggregation of monitoring results". ${ }^{42}$ Scientific and technological advances in the meanwhile are expected to improve the success and efficiency of monitoring programs by the development and testing of novel techniques for trend detection. ${ }^{43}$

The aim of our work was to provide the scientific basis of science-policy integration needs [e.g. ref. 44], by assessing the capabilities and efficiency of various tools to detect and extrapolate trends in groundwater quality. We compared several novel techniques to detect trends in groundwater quality, that are not included in the EU guidance documents to a statistical approach for trend detection, as discussed in the EU guidance. ${ }^{45}$ The following four approaches for the detection and extrapolation of trends in groundwater quality were included in the analysis: (1) statistical methods, (2) groundwater dating, (3) transfer functions, and (4) deterministic modeling. The comparison was based on the analysis of monitoring datasets at four different locations in a variety of different groundwater systems, ranging from unconsolidated unconfined aquifers to fissured dual-porosity systems, representing different types of hydrogeological settings.

\section{Four approaches to trend analysis}

\subsection{Statistical trend detection and estimation}

The success of a statistical trend analysis largely depends on selecting the right statistical tools ${ }^{46}$ considering various aspects of the available data: whether the data are normally distributed or can be described by an alternative distribution function, whether 
the data contain seasonality, ${ }^{47}$ whether the trend is monotonic or abrupt ${ }^{48}$ and whether the trends are expected to be univariate or multivariate. ${ }^{49}$ Loftis $^{24}$ suggested that a clear definition of "trend" should be adopted before analyzing the data. Here we define a temporal "trend" as a significant change in groundwater quality over a specific period of time, over a given region, which is related to land use or water quality management.

The aim of the statistical methods deployed on three of the test sites was to detect and estimate statistically significant changes in the concentrations of contaminants over time. The methods had to be robust and applicable to typical groundwater quality time series, with a limited amount of data, a rather short observation period with possibly missing data, often non-normally distributed, either annually sampled or containing seasonal trends. To meet these requirements, a three-step procedure was adopted ${ }^{22}$ following Hirsch et al. ${ }^{48}$ First, time series were tested for normality; second, the presence of a trend was assessed; and third, the slope of the trend was estimated. The procedure (Fig. 2) was applied to various time series from different study sites.

To test the data for normality, the Shapiro-Wilks test ${ }^{50}$ was applied to datasets with less than 50 records, while the ShapiroFrancia test ${ }^{51}$ was applied to datasets containing 50 or more records. On time series which were normally distributed, a linear regression was performed. The correlation coefficient was used to

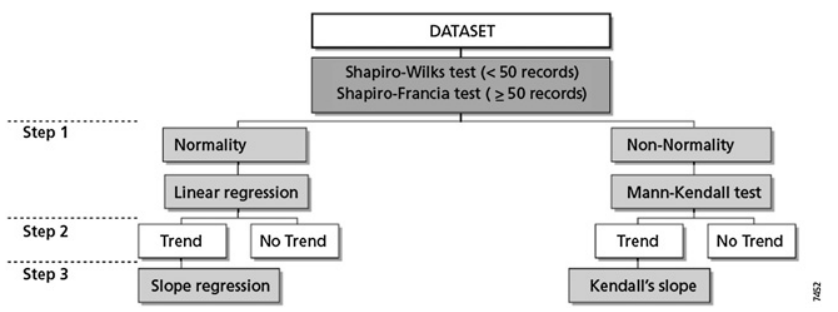

Fig. 2 A three-step procedure is adopted for statistical trend analysis of contaminant concentrations in the selected groundwater bodies: (1) normal/non-normal distribution data; (2) trend detection; (3) trend estimation (after ref. 22).

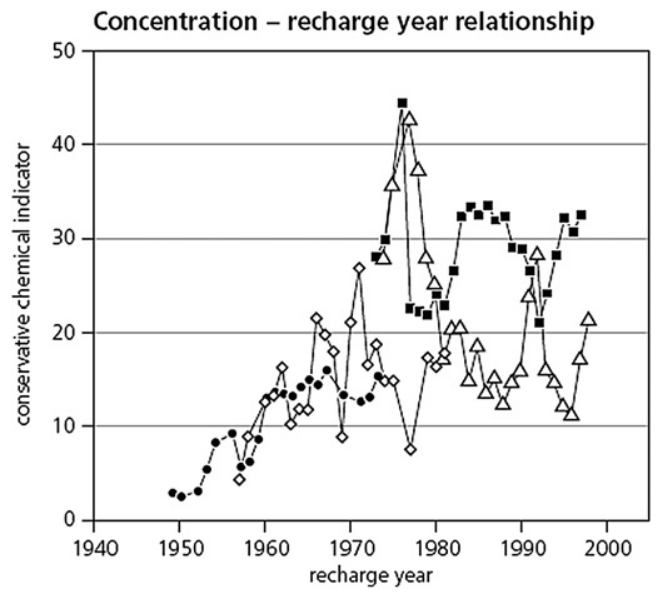

assess the robustness of the trend. ${ }^{52}$ On time series with a nonnormal distribution, the non-parametric Mann-Kendall test, ${ }^{53,54}$ was performed. This test is commonly used in hydrological sciences since its appearance in the paper by Hirsch et al. ${ }^{47}$ as it is rather insensitive to outliers ${ }^{55}$ and has recently been proven as powerful as the Spearman's $\bar{\rho}$ test. ${ }^{56}$ If a significant trend was detected (based on a 95\% significance level), the slope of the trend was determined as the slope of the linear regression equation for normally distributed time series, or using Kendall's slope for non-normal time series. ${ }^{48}$ To aggregate the trend analysis over the entire groundwater body, the number of significant trends was expressed as a percentage. Additional analyses could include the determination of the median trend, or the spatial distribution of trends across groundwater bodies. This approach was applied using various commercial or open-source statistical software packages.

\subsection{Groundwater dating}

Groundwater dating as a tool to aid trend detection was applied on all four datasets. Groundwater dating requires the possibility to accurately sample a range of groundwater age tracers, preferably ${ }^{3} \mathrm{H} /{ }^{3} \mathrm{He},{ }^{57}$ or $\mathrm{CFCs}^{58}$ and/or $\mathrm{SF}_{6}{ }^{59}$ If these gaseous tracers are impractical, a qualitative approach based on ${ }^{3} \mathrm{H}$ measurements alone can be applied to distinguish between old (recharged prior to 1950) and young (recharged after 1950) groundwater. The aim of groundwater dating is to remove the travel time of groundwater as a complicating factor for trend analysis and aggregate monitoring data from wells across groundwater bodies. This was obtained by relating measured concentrations directly to the time of recharge (Fig. 3).

\subsection{Transfer functions to predict future trends}

The aim of the transfer function approach deployed in the dataset from the Brévilles catchment in France was to detect and extrapolate trends in the concentrations of agricultural contaminants in macro-porous or dual-porosity systems where concentrations are strongly correlated to other hydrological
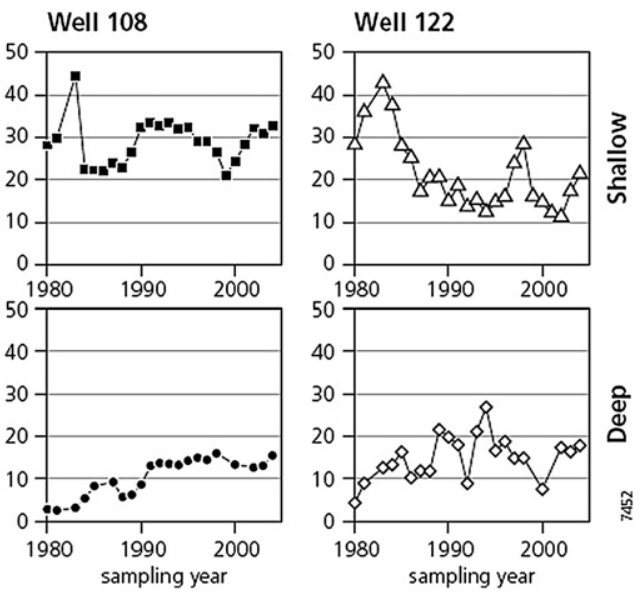

Fig. 3 Example of the use of groundwater dating as a tool to aid trend detection. The concentrations of a conservative chemical indicator (OXC) sampled from the shallow $(8 \mathrm{~m})$ and deep $(24 \mathrm{~m})$ screens of two observation wells. Concentrations are plotted at the time of sampling (right) and plotted at the recharge year of the sampled groundwater (left). The result is the concentration-recharge year relationship, from which a clear trend can be observed that was not visible in the individual time series related to sampling year (after ref. 32). 
parameters, such as precipitation or stream flow. Following the approach described by Pinault et al., ${ }^{60}$ transfer functions were identified and applied using the TEMPO tool ${ }^{61}$ which is capable of modeling time series through iterative calibrations of combinations of transfer functions. The effect of transformation processes on the contaminant concentrations was implicitly incorporated in the transfer functions.

\subsection{Physical-deterministic modeling}

The aim of using physical-deterministic models was to predict future trends in groundwater quality in systems of varying complexity considering changes in the pressure applied to the groundwater system. Distributed groundwater flow and transport models were developed separately and specifically for three sites. Transport models included advective transport, hydrodynamic dispersion and, where necessary, dual-porosity effects, sorption and degradation of contaminants. Predictions of future concentrations were based on scenarios of land use and agricultural application of fertilizer and pesticides, as well as climate scenarios.

\section{Test sites and datasets}

Groundwater bodies were selected at four distinctly different locations to evaluate trend detection methods: the Dutch part of the Meuse basin, a number of catchments in the Belgian part of the Meuse basin, the Brévilles catchment in France and the German Bille-Krückau watershed in the Elbe basin (Fig. 4). The characteristics of each of the test sites and available data are summarized in Table 1 and described in the following sections. The test sites vary strongly in geohydrological characteristics and were studied in different contamination settings (nitrate, pesticides). The contaminants under study were the ions of nitrate

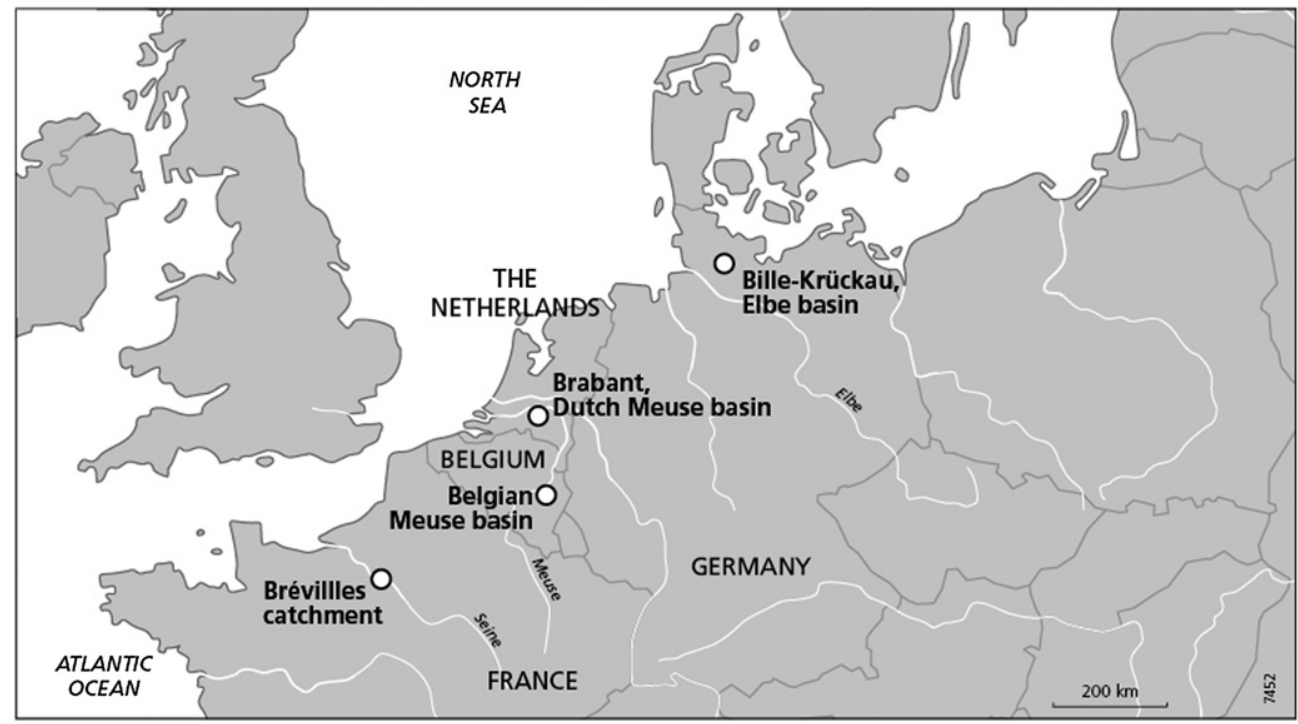

Fig. 4 Location of test sites within Europe.

Table 1 Selected characteristics of the four test sites

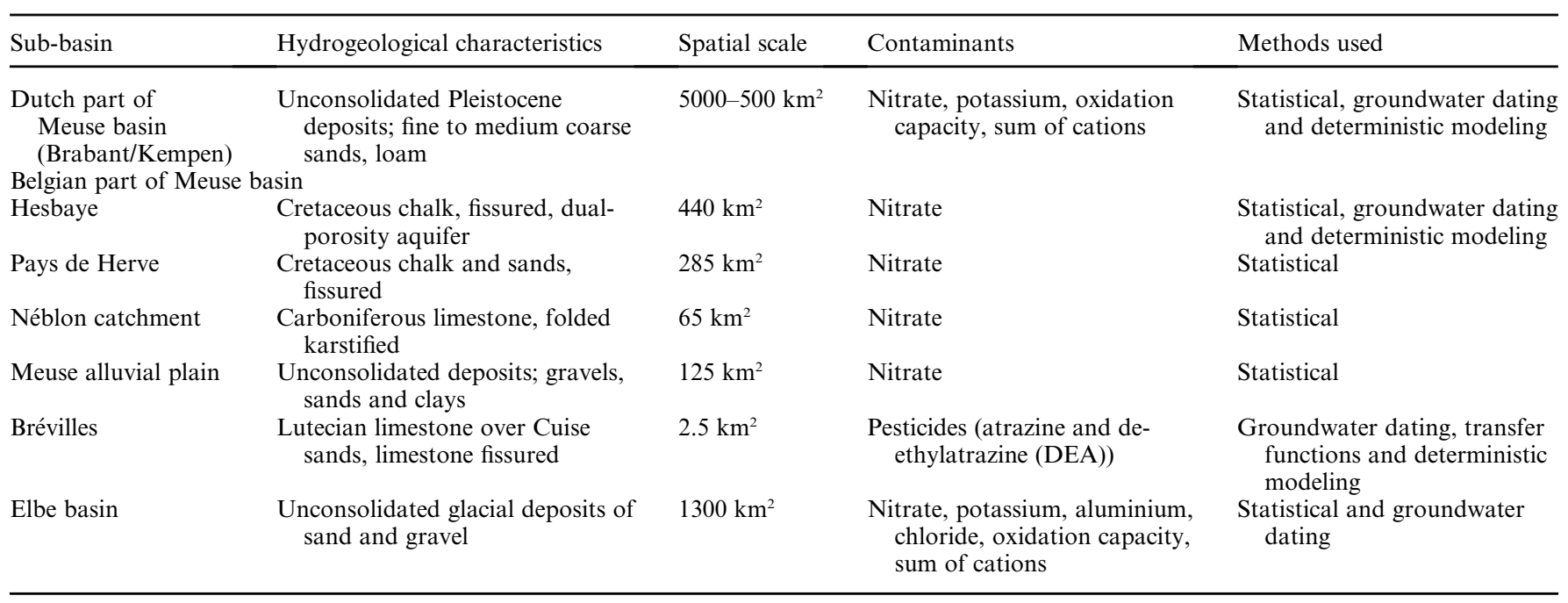


$\left(\mathrm{NO}_{3}\right)$, sulfate $\left(\mathrm{SO}_{4}\right)$, potassium $(\mathrm{K})$, aluminium $(\mathrm{Al})$, and chloride $(\mathrm{Cl})$, as well as combined chemical indicators oxidation capacity (OXC) and charge-weighted molar sum of cations (SUMCAT). OXC is the weighted sum of molar concentrations of $\mathrm{NO}_{3}$ and $\mathrm{SO}_{4}$ which acts as a conservative solute if denitrification by pyrite oxidation takes place. ${ }^{20}$ Furthermore, the concentrations of atrazine and its degradation product de-ethylatrazine (DEA) have been studied. To avoid the detection of artificial trends due to changes in the detection limit over the span of time series, all data were treated as follows before trend analysis. The largest detection limit of a dataset was accepted as the lowest detectable value, and all measurements below this value, including the measurements actually below the detection limit, were set to one half of the detection limit. For details on the sampling and measurement procedures we have referred to other papers if possible.

\subsection{Dutch Meuse basin}

The Dutch part of the Meuse basin almost entirely belongs to the groundwater body Sand Meuse, which covers most of the province of Noord-Brabant and part of Limburg $\left(5000 \mathrm{~km}^{2}\right.$ in total). The groundwater body consists of fluvial unconsolidated Pleistocene sands, covered by $2-30 \mathrm{~m}$ of fluvio-periglacial and aeolian deposits of fine sands and loam. The history of intensive livestock farming on $62 \%$ of the area has produced a large surplus of manure contributing to widespread agricultural pollution (Appendix of ref. 32). The relatively flat area $(0-30 \mathrm{~m}$ above mean sea level) is drained by a natural system of brooks, extended in the 20th century with drains and ditches to allow agricultural practices in the poorly drained areas. Groundwater tables are $1-5 \mathrm{~m}$ below surface as a result. ${ }^{62}$ Net groundwater recharge is around $300 \mathrm{~mm}$ per year resulting in a downward groundwater flow velocity of about $1 \mathrm{~m}$ per year in recharge areas. ${ }^{63}$

Time series of major cations, anions and trace metals are available since 1992 from the dedicated national and provincial monitoring network sampled annually from $2 \mathrm{~m}$ long screens in multilevel wells at depths of $8 \mathrm{~m}$ ("shallow") and $25 \mathrm{~m}$ ("deep") below the surface. ${ }^{20}$ Thanks to the dedicated monitoring wells with short screens and the character of the aquifer, little mixing occurs between recharge and sampling and a groundwater sample is estimated to contain a mixture of water recharged within a period of less than 5 years.

\subsection{Belgian Meuse basin}

Four groundwater bodies were selected as test cases in the Walloon part of the Meuse basin in Belgium, which represent various hydrogeological settings: the cretaceous chalk of Hesbaye, the cretaceous chalk of Pays de Herve, the Néblon basin in the carboniferous limestone of the Dinant synclinorium, and the alluvial plain of the Meuse River.

The cretaceous chalk groundwater body of Hesbaye also referred as the Geer basin covers an area of $440 \mathrm{~km}^{2}$ located north-west from Liège. ${ }^{64}$ The groundwater body is drained by the Geer River, a tributary of the Meuse River. Twenty-five million $\mathrm{m}^{3}$ of groundwater are pumped annually from the fissured dualporosity chalk aquifer to supply the city of Liège and surrounds.
$85 \%$ of the area of the Hesbaye groundwater body is covered intensively by agriculture, mostly crops leading to an important and increasing nitrate contamination of the groundwater resource. Time series of nitrate are available from 32 monitoring points in the groundwater body, varying from dedicated monitoring wells to pumping wells, traditional wells, springs and galleries. ${ }^{22}$

The chalk groundwater body of Pays de Herve covers an area of $285 \mathrm{~km}^{2}$, about $80 \%$ of which is covered by grassland. Groundwater is pumped at a rate of 12 million $\mathrm{m}^{3}$ per year from the chalk aquifer. Nitrate concentrations of over $100 \mathrm{mg} \mathrm{l}^{-1}$ are observed in some of the 59 monitoring points which are distributed throughout the groundwater body.

The Néblon basin covers an area of $65 \mathrm{~km}^{2}$ in the "Entre Sambre et Meuse" groundwater body, built of $500 \mathrm{~m}$ thick folded and karstified carboniferous limestone and sandstone. Land use is mainly divided between pastures $(42 \%)$, crops $(31 \%)$, and forests $(24 \%)$. Around 10 million $\mathrm{m}^{3}$ of groundwater are pumped annually from the limestone aquifers. Nitrate concentrations have been monitored since 1979 at two of the six monitoring locations in the basin.

The alluvial plain of the Meuse groundwater body $\left(125 \mathrm{~km}^{2}\right.$ along $80 \mathrm{~km}$ of the Meuse) consists of gravel bodies embedded in old meandering channels filled with clay, silt and sandy sediments. Land use is $40 \%$ residential or industrial, and $60 \%$ natural land. Time series of groundwater quality data are available from 47 monitoring points.

\subsection{Brévilles catchment}

The Brévilles catchment $\left(2.8 \mathrm{~km}^{2}\right), 75 \mathrm{~km}$ to the north-west of Paris, France, is built up out of a thick unsaturated zone $(0-35 \mathrm{~m})$ of dual-porosity Lutecian limestone, overlying the Cuise sands, $8-20 \mathrm{~m}$ thick and outcropping in the west of the catchment. ${ }^{65}$ There is no superficial drainage and the catchment is drained by the Brévilles spring, an outcrop of the Cuise sands. Land use is largely agricultural, with predominantly peas, wheat and maize ${ }^{66}$ Monthly time series of concentrations of atrazine and its degradation product de-ethylatrazine (DEA) are available from seven piezometers and the Brévilles spring since 2001. ${ }^{67}$ The application of atrazine on the catchment was halted in 2000 .

\subsection{Elbe basin}

The groundwater bodies in the Bille-Krückau watershed $\left(1300 \mathrm{~km}^{2}\right)$, located in Schleswig-Holstein, northern Germany, consist of unconsolidated glacial deposits of sand and gravel. ${ }^{68}$ The sediments were deposited during the last and previous glaciations and subsequently denudated to a plateau-like landscape approximately $40 \mathrm{~m}$ above mean sea level. The area is drained by a dense network of natural streams, of which the Bille River is the largest draining $335 \mathrm{~km}^{2}$. Groundwater is abstracted for drinking water purposes from the sandy and gravely deposits.

Two groundwater quality monitoring networks are in place, aimed at describing the natural conditions (baseline) and detecting trends in groundwater quality (trend). From these networks composed of 27 observation screens in total we selected 19 time series, sampled bi-annually from 8 shallow $(<12.5 \mathrm{~m}$ below surface) and 11 deep ( $>12.5 \mathrm{~m}$ below surface) monitoring 
wells. The time series contain the concentrations of major cations and anions, from which we selected $\mathrm{K}, \mathrm{NO}_{3}, \mathrm{Al}$ and $\mathrm{Cl}$, and constructed OXC and SUMCAT, for trend analysis.

\section{Results}

\subsection{Application of statistical trend detection and estimation}

Statistical trend analysis was applied to the dataset of 34 time series of concentrations from the Dutch part of the Meuse basin. Investigated solutes were $\mathrm{NO}_{3}$ and $\mathrm{K}, \mathrm{OXC}$ and SUMCAT. The time series from shallow screens ( $\sim 8 \mathrm{~m}$ below surface) and deep screens ( $\sim 25 \mathrm{~m}$ below surface) were analyzed separately. Nonparametric statistical trend analysis demonstrated significant trends for OXC and SUMCAT concentrations: increasing in deep screens and decreasing in shallow screens. No significant trends for $\mathrm{NO}_{3}$ were detected.

Statistical trend analysis was applied to 97 nitrate time series from the Belgian part of the Meuse basin (Table 2). Significant trends were detected in $60 \%$ of the time series. Most of the detected trends were increasing, except for the Meuse alluvial plain, where both increasing and downward trends were detected. For 36 time series in the Geer basin, the estimated slope was used to predict the year in which the concentration of nitrate would exceed the drinking water limit $\left(50 \mathrm{mg}^{-1}\right)$. For most of the points, the drinking water limit is estimated to be exceeded within 10-70 years. ${ }^{22}$ This estimate represents a worst-case scenario, as it does not assume changes in land use and agricultural practices to protect groundwater quality.

Finally, statistical trend analysis was applied to the time series of $\mathrm{NO}_{3}, \mathrm{~K}, \mathrm{Al}, \mathrm{OXC}, \mathrm{Cl}$ and SUMCAT concentrations from the Bille-Krückau watershed in the Elbe basin (Table 3). Time series from shallow and deep screens were analyzed separately. For the conservative solutes $\mathrm{Cl}$, OXC and SUMCAT, significant upward trends were detected in time series from deep monitoring screens (>12.5 m below surface), whereas significant decreasing concentrations were detected in time series from the shallow screens (>12.5 m below surface). A further analysis of spatially weighted means indicated significant downward trend of

Table 2 Summary of results for trend tests for each groundwater body in the Belgian part of the Meuse basin

\begin{tabular}{lllll}
\hline $\begin{array}{l}\text { Groundwater } \\
\text { body }\end{array}$ & $\begin{array}{l}\text { Number of } \\
\text { nitrate } \\
\text { sampling sites }\end{array}$ & $\begin{array}{l}\text { Number of } \\
\text { downward } \\
\text { trends }\end{array}$ & $\begin{array}{l}\text { Number of } \\
\text { upward } \\
\text { trends }\end{array}$ & $\begin{array}{l}\text { Percentage of } \\
\text { significant } \\
\text { trends }\end{array}$ \\
\hline Geer basin & 26 & 0 & 15 & 57.7 \\
Pays of Herve & 12 & 2 & 6 & 66.6 \\
Néblon basin & 6 & 1 & 4 & 83.3 \\
Alluvial plain & 38 & 15 & 11 & 68.4 \\
\hline
\end{tabular}

Table 3 Percentage of the individual time series of the Bille-Krückau dataset showing a significant trend ( $\Uparrow$ : significant upward trend, $\Downarrow$ : significant downward trend)

\begin{tabular}{lllllll}
\hline & $\mathrm{NO}_{3}$ & $\mathrm{~K}$ & $\mathrm{Al}$ & $\mathrm{OXC}$ & $\mathrm{Cl}$ & SUMCAT \\
\hline Shallow & - & $40 \% \Downarrow$ & $0 \%$ & $20 \% \Downarrow$ & $20 \% \Downarrow$ & $20 \% \Downarrow$ \\
Deep & - & $11 \% \Downarrow$ & - & $33 \% \Uparrow, 11 \% \Downarrow$ & $44 \% \Uparrow$ & $11 \% \Uparrow$ \\
\hline
\end{tabular}

potassium in shallow screens and significant upward trends of chloride and sum of negative ions. Significant trends were not detected in deep screens.

\subsection{Application of groundwater dating}

${ }^{3} \mathrm{H} /{ }^{3} \mathrm{He}, \mathrm{CFC}$ and $\mathrm{SF}_{6}$ groundwater ages were available from 34 screens of 14 wells in agricultural recharge areas in the Dutch part of the Meuse basin. ${ }^{69,70} \mathrm{CFC}$ samples showed irregularities attributed to degassing caused by denitrification and contamination. ${ }^{70}{ }^{3} \mathrm{H} /{ }^{3} \mathrm{He}$ ages were considered more reliable following internal checks on degassing or contamination. The ${ }^{3} \mathrm{H} /{ }^{3} \mathrm{He}$ ages were used to interpret the time series of concentrations, by relating concentrations to the estimated time of recharge and aggregating all data available for the entire groundwater body. ${ }^{32}$ The aggregated data were analyzed using a LOWESS smooth ${ }^{55}$ with a smoother span of 0.5 to indicate the general pattern of change and compare that to contamination history and trends in the aggregated data were detected using simple linear regression to detect trends in concentrations in groundwater recharged between 1960 and 1980, or between 1990 and 2000 (Fig. 5). Significant upward trends were found in the concentrations of $\mathrm{NO}_{3}, \mathrm{~K}, \mathrm{OXC}$ and SUMCAT in "old" groundwater (recharged between 1960 and 1980), but also significant downward trends were found in the concentrations of $\mathrm{NO}_{3}, \mathrm{OXC}$ and SUMCAT in young groundwater (recharged between 1990 and 2000). Trends detected in this way could directly be related to changes in land use or contamination history. These results demonstrated trend reversal in groundwater quality ${ }^{32}$ on the relevant scale of a groundwater body, as required by the EU Groundwater Directive. $^{6}$

Tritium samples were taken from 33 monitoring points in the Geer basin and analyzed by the Lab of radioactive isotopes of the UFZ, Leipzig, Germany. The distribution of tritium concentrations only shows a distinction between "old" (>50 years) and "young" groundwater (Fig. 6), because travel times cannot be estimated accurately and unequivocally based on the tritium concentration only. High concentrations of tritium were observed in a large southwestern portion of the basin, where recharge is assumed to take place. Toward the downstream end of the basin, tritium concentrations decrease, indicating mixing of younger and older groundwater. No tritium is found in the northern confined part of the basin, indicating old $(<1950)$ groundwater. The presence of old groundwater explains the absence of nitrate in this part of the aquifer.

The interpretation of groundwater age tracers $\left({ }^{3} \mathrm{H}\right.$ and CFCs) is not straightforward in hydrogeological complex systems like the Brévilles catchment. An experimental sampling campaign was performed to assess whether an extensive dataset of groundwater age tracers would provide additional knowledge on the functioning of the system. Tritium and CFCs were analyzed in samples taken from 8 piezometers and the Brévilles spring. ${ }^{71,72}$ The estimated ages showed a high variability within the small catchment with both old $(<1960)$ and young $(>1980)$ water in close proximity. The individual CFC ages (CFC-11, CFC-12, and CFC-113) were generally in good agreement, but some samples showed signs of degradation or contamination. Qualitative tritium groundwater age estimates were generally younger than the CFC age due to the dual-porosity nature of the system. 

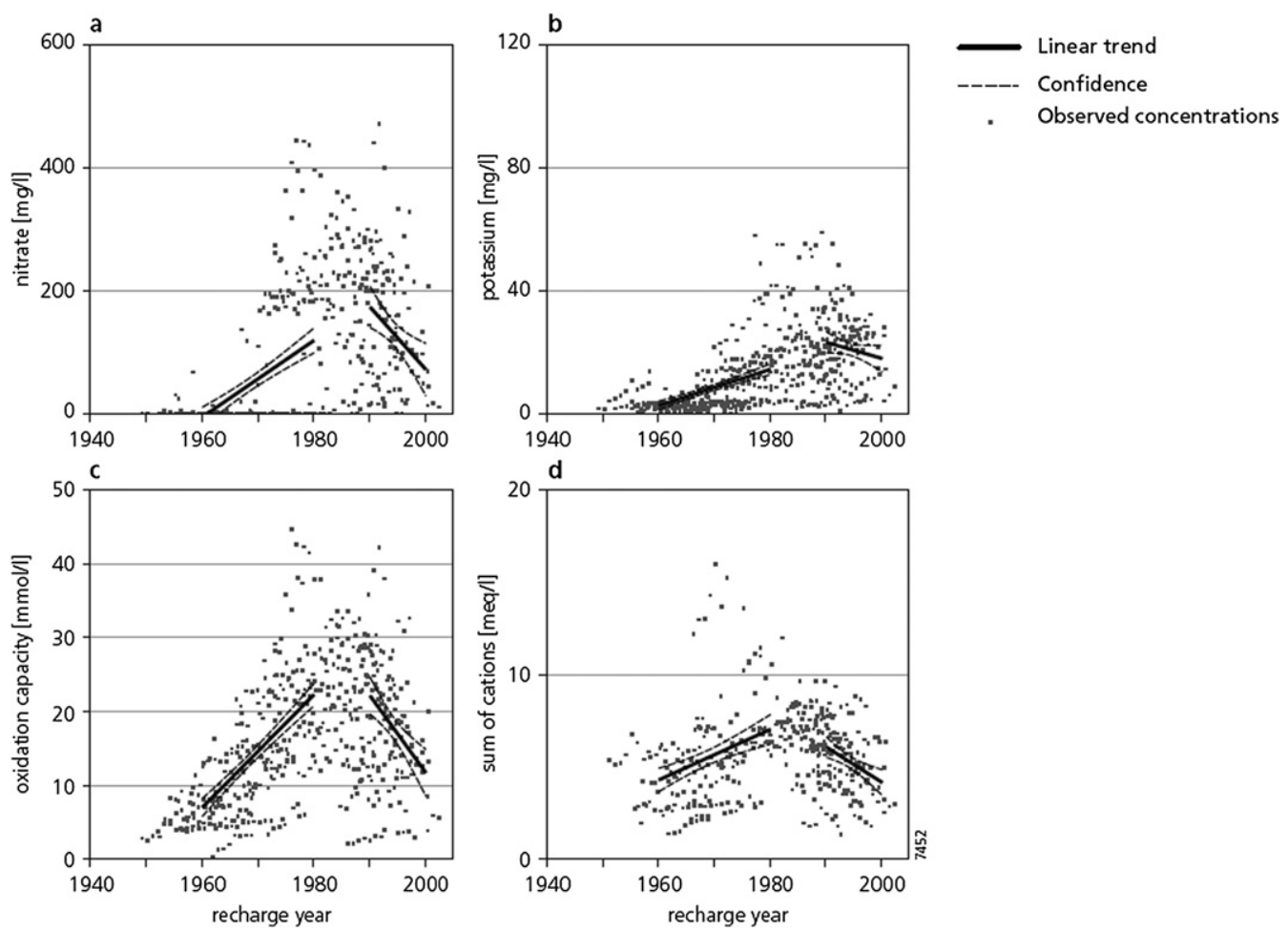

Fig. 5 Linear trends through concentration-recharge year data from the Dutch part of the Meuse basin show significant trend reversal between 1980 and 1990 for nitrate (a), oxidation capacity (c) and sum of cations (d) (after ref. 32). Potassium (b) showed no significant trend reversal.
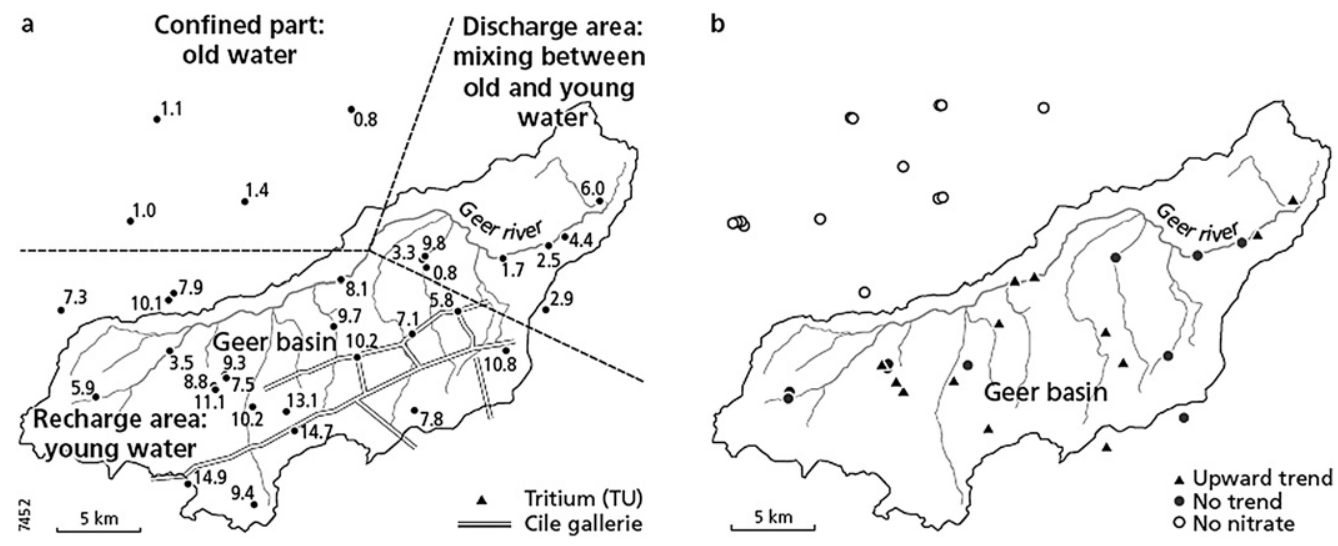

Fig. 6 Spatial distribution of tritium (a) and trends in nitrate concentrations (b) in the Geer basin (after ref. 22).

The tracers confirmed the complex hydrogeology of the system, but could not be used for reliable age dating and trend interpretation because of the likely mixing co-occurring in the thick unsaturated zone.

For the Elbe dataset, an empirical exponential relationship between depth and groundwater age was assumed, instead of dating groundwater using tracers. Such an exponential increase in groundwater age with depth may be expected in unconsolidated unconfined aquifers like the Bille-Krückau catchment. ${ }^{73}$ Using the empirical relationship, the time series of $\mathrm{Cl}, \mathrm{OXC}$ and SUMCAT were related to the approximate time of recharge and analyzed again for trends using a LOWESS smooth with a smoother span of 0.5 and a linear trend detection with a $95 \%$ confidence interval (Fig. 7). The LOWESS smooth approach showed that the overall pattern in the measured concentrationrecharge time relationship is similar to the historical surplus of $\mathrm{N}$ applied at the surface. Similar results were found in the Dutch part of the Meuse basin, probably due to the similarities in land use history and hydrogeology.

\subsection{Application of transfer functions}

The transfer function approach was applied to time series of head, flux, and nitrate, atrazine and DEA concentrations from the piezometers and spring in the Brévilles catchment. The following section describes the followed approach, which has been described in detail by Pinault and Dubus. ${ }^{66}$ Hydraulic heads were modeled as a function of effective rainfall using combined 

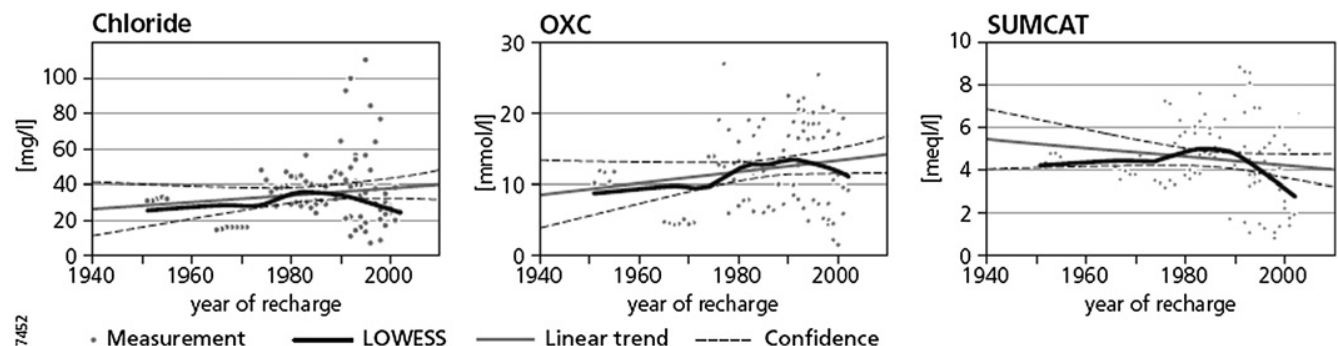

Fig. 7 Linear trends (with 95\% confidence interval) and LOWESS smooth lines through concentrations of Cl, OXC, and SUMCAT in relation to time of recharge from the Elbe basin.

convolution functions for transport and dispersion, while effective rainfall was modeled as a function of the actual rainfall and of a threshold value representing the water storage in the soil. The threshold value for soil water storage was related to the rainfall and potential evapotranspiration with trapezoid impulse response functions with four degrees of freedom. Concentrations of contaminants were modeled in a similar fashion, using the effective flux of the contaminant from the unsaturated soil instead of the effective rainfall, to predict the flux or concentrations in the Brévilles spring. To predict spring fluxes and concentrations, the impulse response functions were extended to include the contribution of various pathways of contaminants to the spring. Future concentrations were calculated based on 5 year long generated meteorological time series based on the median annual precipitation and the 5, 10 and 20 year extreme wet and dry years.

The transfer function model was capable of reproducing the general trends in the time series, both in the monitoring wells and in the spring. We think the good fit is remarkable given the short monitoring period and the long travel times in the groundwater system, as indicated by impulse response functions of over 10 years long. Because of these long transfer times, it was possible to reconstruct the concentrations of the contaminants in the vadose zone. Interestingly, the reconstructed inputs were in agreement with the historical application of atrazine in the catchment.

Future concentrations of atrazine and DEA at the Brévilles spring were predicted using the calibrated transfer function model and rainfall data generated by the TEMPO tool (Fig. 8). The generated rainfall series contained either only wet or dry years, with historical recurrence intervals of 5,10 or 20 years, to illustrate the response of atrazine concentrations to different future climates. Atrazine release was predicted to occur more during wet years than in dry years. While atrazine concentrations in the spring are predicted to decrease dramatically over the next 5 years, concentrations of its metabolite DEA are expected to remain constant over the next decade. ${ }^{66}$

\subsection{Application of deterministic modeling}

For the Kempen region in the Dutch part of the Meuse basin, the physical-deterministic groundwater flow and transport models were a steady-state MODFLOW ${ }^{74}$ model for groundwater flow and $\mathrm{MT}^{\mathrm{D}} \mathrm{DMS} \mathrm{S}^{75}$ for solute transport. Historical concentrations of contaminants at the land surface were reconstructed based on statistical records of atmospheric depositions and manure applications. ${ }^{76}$ Leaching of heavy metals from the unsaturated zone, sensitive to sorption and fluctuating water tables, was modeled with Hydrus-1D. ${ }^{77}$ The coupled transport model, described in detail by Van der Grift and Griffioen, ${ }^{\mathbf{4 1}}$ was used to predict concentrations of nitrate, potassium and heavy metals in groundwater at the monitoring locations within the model area.

The model predicted significant trends in the concentrations of nitrate and OXC for the period 1995-2005: upward in deep groundwater and downward in shallow groundwater. Due to variations in groundwater travel times and the constant recharge concentrations from 2005 onward, few significant trends are predicted for the future, except a decrease in OXC between 2010 and 2020. Between 2010 and 2020, the model also predicted a significant upward trend in the concentration of zinc in shallow groundwater. This trend is caused by a slow release of zinc accumulated in the unsaturated zone and the retarded transport of zinc through the groundwater system due to cation exchange. $^{20,41}$

For the Geer basin in the Walloon part of the Meuse basin, a physically based, spatially distributed, deterministic model was constructed using the control volume finite element SUFT3D code. $^{78}$ This model $^{79}$ uses a new approach, the hybrid finite element mixing cell, ${ }^{80}$ combining mixing cells to model the solute transport with a conventional finite element model for groundwater flow based on Darcy's law both in the saturated and in the partially saturated zones. Transport processes considered with the mixing cells are advection, degradation and dual-porosity related to the presence of immobile water. The model was calibrated on groundwater levels, as well as measured tritium concentrations. The model was used to reproduce and to extrapolate observed nitrate concentrations in the Geer basin at the monitoring points.

The model was capable of reproducing both the groundwater levels and the distribution of tritium in the aquifer. The model also accurately reproduced the upward trends in nitrate concentrations in the Geer basin. The future evolution of nitrate trends in groundwater was computed for different scenarios of nitrate concentrations in the leaching water. The time before trend reversal is a function of the location of the monitoring points in the basin. In the Southern part of the basin, time before reversal is a function of the thickness of the unsaturated zone where the nitrates move slowly. In the Eastern part of the basin, due to the mixing between old and young water, trend reversal would not occur in the next 50 years and nitrate concentrations would still increase.

The physical-deterministic model developed for the Brévilles catchment, in France, consisted of the combination of a series of 

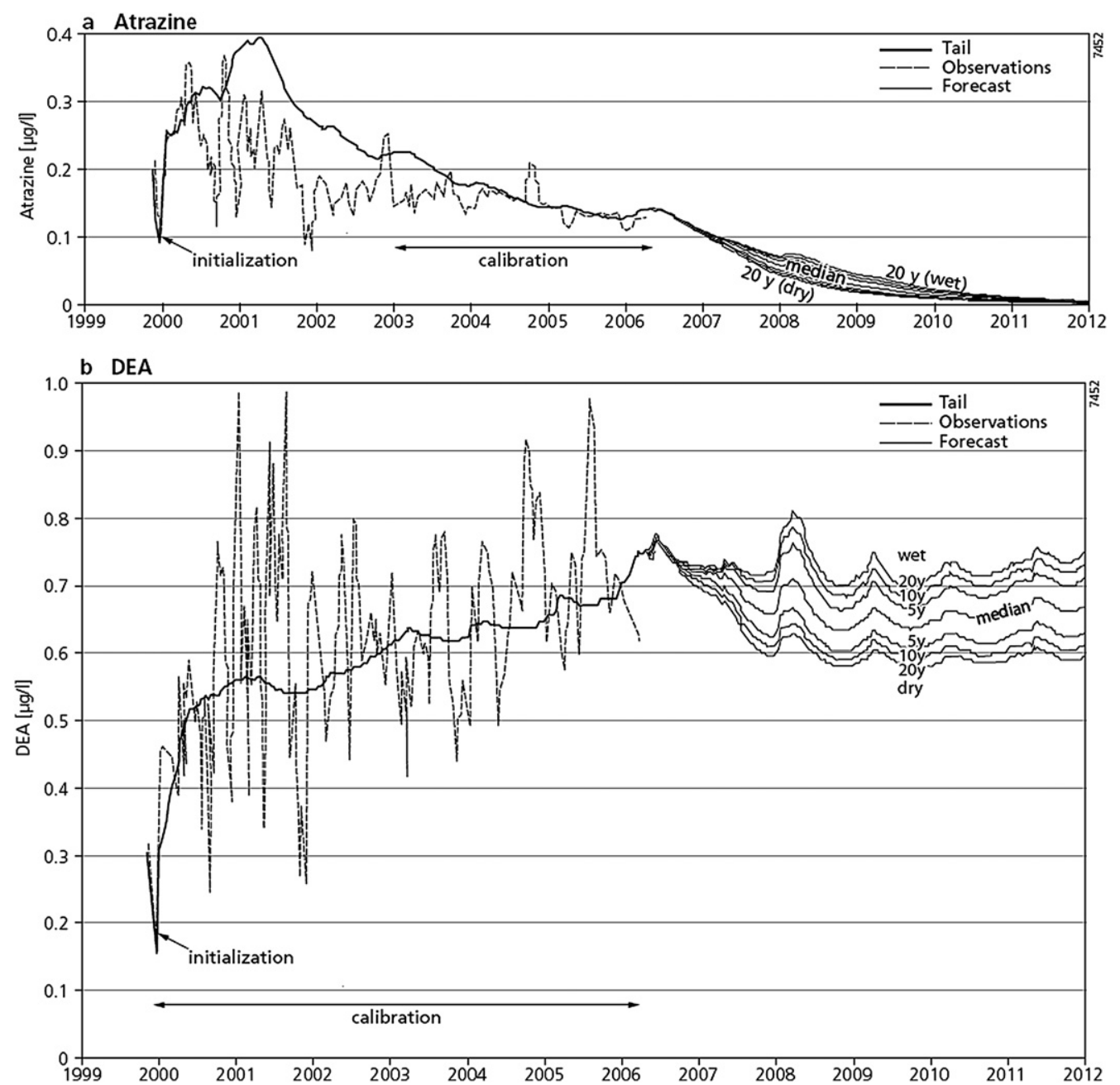

Fig. 8 Predictions of the TEMPO software for concentrations of atrazine and the atrazine metabolite DEA (de-ethylatrazine) at the Brévilles spring (after ref. 66).

a 1D unsaturated zone models to simulate water flow and contaminant transport through the fissured dual-porosity chalk, and a $2 \mathrm{D}$ groundwater flow and transport model for the Cuise sands. The $1 \mathrm{D}$ pesticide fate model $\mathrm{MACRO}^{\mathbf{8 1}}$ was used to simulate transport through the root zone, taking into account preferential flow phenomena, while transport through the unsaturated zone was modeled using MARTHE. ${ }^{82}$ The combined model was used to reproduce observed groundwater levels, as well as nitrate, atrazine and DEA concentrations in piezometers and in the Brévilles spring. Thirteen regional climate model scenarios were used for predicting future trends in concentrations.

This combined model accurately reproduced the observed groundwater levels at the piezometers and also the discharge from the Brévilles spring. Predicted atrazine concentrations at the piezometers were in the same order of magnitude as the measurements, but predicted concentrations underestimated observations in the spring, probably due to the lack of accurate data on the application of atrazine on individual fields in the catchment. Similar to the predictions made using the transfer function approach, concentrations of atrazine in piezometers were predicted to decrease exponentially over the next 14 years.
A slower decline in the concentrations was predicted for the spring.

\section{Discussion of trend detection approaches}

In this section, we discuss each of the methods applied in this study in terms of data requirement, additional monitoring costs, applicability in different geohydrological systems, and their power to extrapolate. Prerequisites, costs, and overall usefulness of all methods are summarized in Table 4.

The statistical three-step approach to detect trends in groundwater quality was applied at three test sites and proved to be a simple and easily applicable technique to existing time series of contaminant concentrations, having a normal distribution or not, making it universally applicable (Table 4). Statistical trend detection requires time series that span several years to decades to detect a significant trend, depending on the hydrogeological system and monitoring network. If the quality of the available datasets is sufficient, it requires no additional costs for sampling. The approach provides an objective detection of trends.

Statistical trend analysis may be of limited operational use because no link to the driving forces (e.g. meteorological data, 


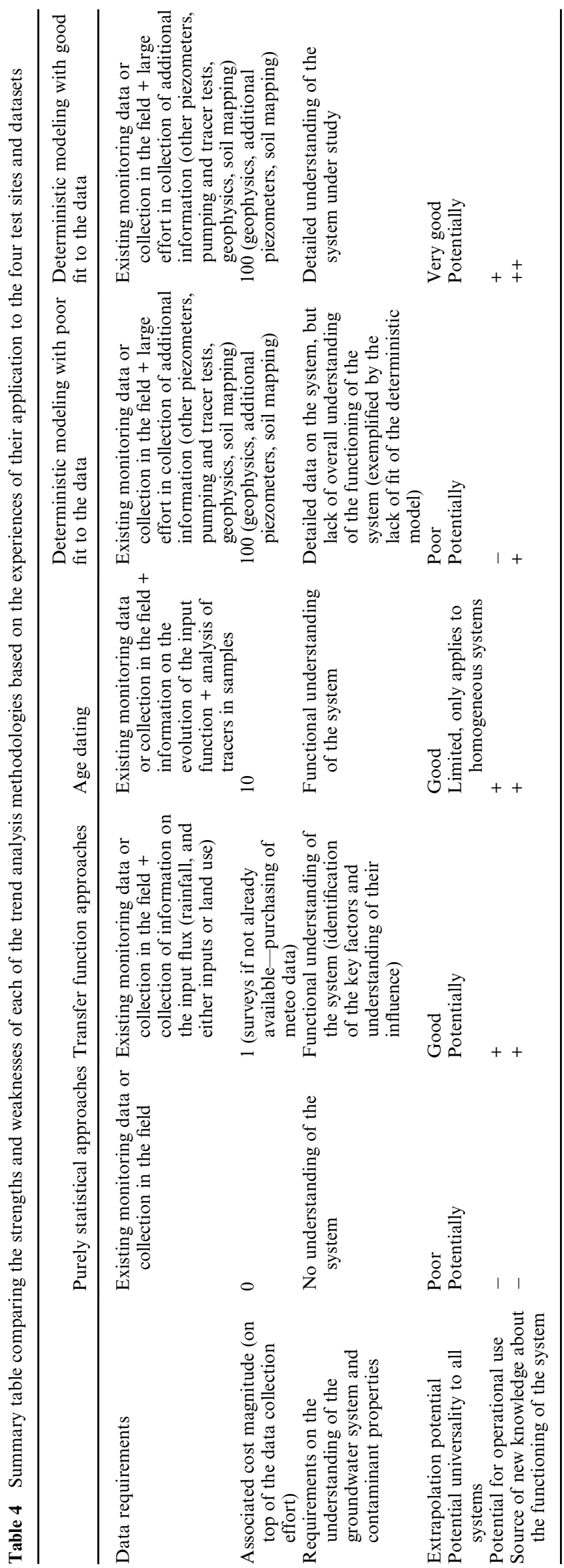

groundwater flow and travel times or historical agricultural practices) is incorporated in the analysis, and no knowledge about the functioning of the system will be gained by its application. Therefore the trends that are found in individual time series may be extrapolated over short periods of time only. Statistical trends cannot sensibly be extrapolated over longer periods of time, because they are incapable of dealing with changes in agricultural practices, meteorological conditions or the groundwater flow system. Statistical trend analysis is not capable of predicting trend reversal, which is a major disadvantage.

Trend detection as required by the GWD is dedicated to detect trends in the concentrations of pollutants resulting from anthropogenic sources and distinguish these from natural variation with an adequate level of confidence and precision (GWD, Annex V, art 2(a)(i)). While the WFD Guidance ${ }^{42}$ left little room to include conceptual understanding of the factors determining groundwater quality, in recent years, it was generally realized that a conceptual understanding of the groundwater systems is essential for the characterization of chemical status and the detection of trends. ${ }^{45,83}$ It is our conclusion that only for an initial survey to detect changes in groundwater quality, a classical statistical approach is most suitable, but more elaborate approaches to trend detection including more information about the groundwater body and contaminant transport may have a higher chance of determining and understanding significant and sustained upward trends or trend reversal.

For the detection of trends in groundwater quality it is crucial to know whether the character of the subsurface or the monitoring system causes mixing of groundwater with different travel times. In single porous systems, groundwater at a specific location typically has a distinct groundwater age. In practice, the possibility of sampling groundwater with a distinct age also requires a monitoring network with short $(<5 \mathrm{~m})$ monitoring screens or the use of packers in long screened wells to prevent mixing during sampling. In simple single-porosity groundwater bodies with access to monitoring wells with short screens, groundwater dating has been applied by various studies as a tool for aggregating groundwater quality data and analyzing trends therein by relating the measured concentrations of pollutants to the time of recharge of the sampled groundwater. ${ }^{23,26,27,29,32,84}$ The resulting concentration-travel time relationship can be linked directly to historical records of land use or agricultural practices. Recent publications presenting studies from the U.S. Geological Survey National WaterQuality Assessment (NAWQA) program in which concentrations are directly related to recharge time of groundwater conclude that groundwater travel times are invaluable to the detection of trends in existing groundwater quality data. ${ }^{14,85-88}$

Groundwater dating can thus be used to reinterpret groundwater quality time series and demonstrate trend reversal in groundwater quality, which represents a step further in comparison with statistical analysis. Knowledge about the travel times in the groundwater system enhances the understanding of the flow system and may also explain the slow improvement of groundwater quality (Table 4). It must be considered that groundwater dating requires a substantial financial investment for sampling and sample analysis, even if 
a proper monitoring network is in place. The benefit is that the existing groundwater quality data become more valuable as the re-analysis of this data may reveal trends that could not be demonstrated without knowledge of the recharge times of the groundwater samples. This makes groundwater dating suitable for operational use, where applicable.

In hydrogeologically complex systems such dual-porosity aquifers, or under a variably or thick unsaturated zone, groundwater age tracers are difficult to interpret and may only confirm the complexity of the system and proper application is limited to more simple groundwater systems. Qualitative groundwater dating using tritium can be applied to detect the presence of "old" groundwater, which may for example explain the presence of nitrate at low concentrations due to old age rather than denitrification. In such complex systems, possibly with seasonal influences, a transfer function approach is likely to be better suited for trend detection.

The transfer function approach is an intermediate approach between statistical and deterministic models. If the available data are sufficient to calibrate a transfer function that expresses the delay in transfers of water and pollutants in the systems considered, transfer functions require no additional financial investment (Table 4). The main advantages of transfer functions are that they require little information about the physical functioning of the system, but rather rely on the available data, which make them suitable for application in a wide variety of systems.

Transfer functions provide a good agreement with measured time series in the complex aquifer of the Brévilles catchment showing that they are capable of reproducing the non-linear behavior of dual-porosity systems, ${ }^{66}$ where other approaches failed. This makes them suitable for operational use in these systems, if the transfer functions are capable of providing a representative description of the system and its variability. Transfer functions may be used for trend extrapolation, but only with great care to ensure that the predicted trends are within the range of the observations. In these systems, groundwater dating may serve to confirm the hydrological functioning and transfer times of the system.

Because of the geohydrological diversity among test sites, sitespecific physical-deterministic models need to be built. One of the main issues associated with deterministic modeling is the need to have a detailed characterization of the system under study available in terms of meteorology, soils, subsoils, hydro(geo)logy and use of pollutants on the catchment. Furthermore, the relevant characteristics of water flow, transport and interactions between the contaminants and the system itself need to be known at the effective scale of the model, while many of these parameters are often derived from laboratory studies. This typically requires very significant financial and time investments in the field, which usually spans over several years. On the other hand, one of the great advantages of undertaking deterministic modeling activities is that it brings together various sources of information collected in the field that allow the expansion of the understanding of the catchment functioning using both measured and predicted information. Although there is no dispute as to the usefulness of intensive catchment modeling activities from a research point of view, the 'return on investment' from an operational perspective is mainly dependent on whether a model can be successfully fitted to the data and whether the model has shown potential for supporting extrapolation and management activities. A distinction was therefore made in Table 4 between modeling efforts which provide a successful fit to measured data and trends, and those where the fit to the data is considered to be below the standard for operational activities.

The very large financial, human resources and time investments associated with the collection of data and their integration into an overarching modeling exercise means that the deployment of deterministic models for operational analysis of trends across the EU is beyond reach, even if a good fit to the data would be obtained. Such modeling activities should concentrate on areas of high ecological, sustainability or economical importance within the context of the Water Framework Directive.

The main advantage of physically deterministic models is their capability to predict trends in the future that are not yet observed in the monitoring data, for example due to the slow release of zinc from the unsaturated zone. They can provide estimates of the time scales at which trend reversal should be expected as a result of protective legislation, which may be several decades because of the long travel times of groundwater. ${ }^{41}$ While largescale 3D models are suitable to extrapolate long-term trends, they are less capable of predicting short-term variations due in part to their coarse resolution and simplified aquifer characteristics. The quality of predicted future trends relies on the appropriate incorporation of important processes into the model, the fit of the model to the existing data, and accuracy of future land use, agricultural practices, and contamination scenarios. Such scenario analyses are useful to aid policy makers to decide on the effectiveness of proposed regulations.

\section{Conclusions}

There is no unique solution to detect trends in groundwater quality across widely differing catchments and monitoring systems. The choice of the method for trend detection and extrapolation should firstly be made on the basis of the specific goals of the study (only trend detection or also extrapolation), the available resources, and the system under study (Table 5). Among the aspects of trend detection investigated in this study, the most important difference between groundwater bodies is whether the character of the subsurface or the monitoring system causes mixing of groundwater with different travel times. While statistical trend detection may be suitable for preliminary surveys of trends in groundwater quality in any type of groundwater

Table 5 Recommended preliminary and elaborate methods for trend detection and extrapolation in simple and complex groundwater systems

\begin{tabular}{ccll}
\hline & & Groundwater system \\
\cline { 3 - 4 } Trend detection & Simple & Complex \\
\hline Trend & Elaborate & $\begin{array}{l}\text { Statistics } \\
\text { Groundwater } \\
\text { extrapolationg }\end{array}$ & $\begin{array}{l}\text { Statistics } \\
\text { Transfer functions }\end{array}$ \\
& $\begin{array}{c}\text { Preliminary } \\
\text { (short-term) } \\
\text { Elaborate } \\
\text { (long-term) }\end{array}$ & $\begin{array}{c}\text { Statistical } \\
\text { methods } \\
\text { Deterministic } \\
\text { model }\end{array}$ & Transfer functions \\
\hline
\end{tabular}


body, more elaborate studies aimed at detecting trends should apply groundwater dating in unconsolidated aquifers or transfer functions in complex aquifers. Statistical approaches or transfer functions are suitable only for short-term extrapolation of trends, because no direct link with the driving forces of the trends is included in these methods. Long-term extrapolation requires the use of deterministic models with a good fit to the available data, which are capable of predicting the effects of land use changes and various management scenarios.

Regardless of the complexity of the model used, being transfer functions or deterministic models, trend detection and extrapolation are always associated with uncertainty. This means that groundwater quality monitoring should remain a priority. Additional data will improve the detection of trends and increase the knowledge of the functioning of the groundwater system. Better understanding of the system, possibly derived from deterministic modeling, can in turn provide feedback for the optimization of the groundwater quality monitoring networks.

\section{Acknowledgements}

This work was supported by the European Union FP6 Integrated Project AquaTerra (Project no. GOCE 505428) under the thematic priority "Sustainable development, global change and ecosystems". European Union FP5 Project PEGASE (FP5EVK1-CT1999-00028), Seine River Basin Water Authority (AESN) and the BRGM research project TRANSPHYTO also supported the collection of data in the Brévilles catchment. The Belgian data were acquired thanks to the help of the administration of the Walloon Region (F. Delloye and his team) and the team of the Hydrology \& Agricultural Hydraulics Group of the University of Gembloux, Belgium. Conceptual and numerical developments of the HFEMC method have also been performed in the framework of The Interuniversity Attraction Pole TIMOTHY (IAP Research Project P6/13) funded by the Belgian Federal Science Policy Office (BELSPO). The monitoring data used for the Bille-Krückau catchment were provided by Environmental Office of Schleswig-Holstein State, thanks to the assistance of Dr Henning Holthusen and his colleagues. We would like to thank Sylvia Dautrebande (Gembloux Agricultural University, Belgium) and Tom Nolan and Larry Puckett (USGS) for providing data for Fig. 1. We would like to thank two anonymous reviewers for their comments which helped us improve the manuscript.

\section{References}

1 R. F. Spalding and M. E. Exner, Occurrence of nitrate in groundwater-a review, J. Environ. Qual., 1993, 22(3), 392-402.

2 S. S. D. Foster, A. C. Cripps and A. Smith-Carington, Nitrate leaching to groundwater, Philos. Trans. R. Soc. London, Ser. B, 1982, 296, 477-489.

3 O. Strebel, W. H. M. Duynisveld and J. Böttcher, Nitrate pollution of groundwater in western Europe, Agric., Ecosyst. Environ., 1989, 26(34), 189-214.

4 B. T. Nolan and et al., Risk of nitrate in groundwaters of the United States - a national perspective, Environ. Sci. Technol., 1997, 31(8), 2229.

5 EU, Directive of the European Parliament and of the Council 2000/60/ EC Establishing a Framework for Community Action in the Field of Water Policy, 2000.

6 EU, Directive 2006/118/EC on the Protection of Groundwater against Pollution and Deterioration, 2006.
7 J. Y. Lee and et al., A review of the national groundwater monitoring network in Korea, Hydrol. Process., 2007, 21(7), 907-919.

8 N. J. Kim, M. J. Cho and N. C. Woo, Developing a national groundwater-monitoring network in Korea, Hydrogeol. J., 1995, 3(4), 89.

9 R. K. Juhler and G. Felding, Monitoring methyl tertiary butyl ether (MTBE) and other organic micropollutants in groundwater: results from the Danish national monitoring program, Water, Air, Soil Pollut., 2003, 149(1-4), 145.

10 W. Van Duijvenbooden, Groundwater Quality Monitoring in the Netherlands, in Regional Groundwater Quality, ed. W. M. Alley, Van Nostrand Reinhold, New York, 1993, pp. 515-535.

11 C. J. Daughney and R. R. Reeves, Definition of hydrochemical facies in the New Zealand national groundwater monitoring programme, J. Hydrol. (New Zealand), 2005, 44(2), 105-130.

12 M. N. Almasri and S. M. S. Ghabayen, Analysis of nitrate contamination of Gaza Coastal Aquifer, Palestine, Journal of Hydrologic Engineering, 2008, 13(3), 132-140.

13 P. P. Leahy, B. Ryan and I. Johnson, An introduction to the U.S. geological surveys national water-quality assessment program, Water Resources Bulletin, 1993, 29(4), 529.

14 M. R. Rosen and W. W. Lapham, Introduction to the U.S. Geological Survey National Water-Quality Assessment (NAWQA) of groundwater quality trends and comparison to other national programs, J. Environ. Qual., 2008, 37(S5), 190-198.

15 R. S. Ward and et al., A framework for monitoring regional groundwater quality, Q. J. Eng. Geol. Hydrogeol., 2004, 37(4), 271281.

16 C. J. Daughney and R. R. Reeves, Analysis of temporal trends in New Zealand's groundwater quality based on data from the national groundwater monitoring programme, J. Hydrol. (New Zealand), 2006, 45(1), 41-62.

17 Y. Xu, L. A. Baker and P. C. Johnson, Trends in ground water nitrate contamination in the Phoenix, Arizona Region, Ground Water Monit. Rem., 2007, 27(2), 49-56.

18 M. E. Stuart and et al., Screening for long-term trends in groundwater nitrate monitoring data, Q. J. Eng. Geol. Hydrogeol., 2007, 40(4), 361376.

19 H. P. Broers and and et al., Groundwater quality trend detection at the regional scale: effects of spatial and temporal variability, IAHS Publ., 2005, vol. 297, pp. 50-60.

20 H. P. Broers and B. Van der Grift, Regional monitoring of temporal changes in groundwater quality, J. Hydrol. (Amsterdam, Neth.), 2004, 296(1-4), 192-220.

21 J. Reynolds-Vargas, J. Fraile-Merino and R. Hirata, Trends in nitrate concentrations and determination of its origin using stable isotopes $\left({ }^{18} \mathrm{O}\right.$ and $\left.{ }^{15} \mathrm{~N}\right)$ in groundwater of the western Central Valley, Costa Rica, Ambio, 2006, 35(5), 229-236.

$22 \mathrm{~J}$. Batlle-Aguilar and et al., Identification of groundwater quality trends in a chalk aquifer threatened by intensive agriculture in Belgium, Hydrogeol. J., 2007, 15(8), 1615.

$23 \mathrm{~K}$. Burow, N. Dubrovsky and J. Shelton, Temporal trends in concentrations of $\mathrm{DBCP}$ and nitrate in groundwater in the eastern San Joaquin Valley, California, USA, Hydrogeol. J., 2007, 15(5), 991-1007.

24 J. C. Loftis, Trends in groundwater quality, Hydrol. Process., 1996, 10, 335-355.

25 Regional Ground-Water Quality, ed. W. M. Alley, Van Nostrand Reinhold, New York, 1993.

26 J. K. Böhlke and J. M. Denver, Combined use of groundwater dating, chemical, and isotopic analyses to resolve the history and fate of nitrate contamination in two agricultural watersheds, Atlantic coastal plain, Maryland, Water Resour. Res., 1995, 31(9), 2319-2339.

27 A. M. MacDonald and et al., Identifying trends in groundwater quality using residence time indicators: an example from the Permian aquifer of Dumfries, Scotland, Hydrogeol. J., 2003, 11(4), 504-517.

28 J. K. Böhlke and et al., Denitrification in the recharge area and discharge area of a transient agricultural nitrate plume in a glacial outwash sand aquifer, Minnesota, Water Resour. Res., 2002, 38(7), $1-26$.

29 L. I. Wassenaar, M. J. Hendry and N. Harrington, Decadal geochemical and isotopic trends for nitrate in a transboundary aquifer and implications for agricultural beneficial management practices, Environ. Sci. Technol., 2006, 40(15), 4626-4632. 
30 A. J. Tesoriero and et al., Nitrogen transport and transformations in a coastal plain watershed: influence of geomorphology on flow paths and residence times, Water Resour. Res., 2005, 41(2), W02008.

31 T. Laier, Nitrate Monitoring and CFC-Age Dating of Shallow Groundwaters-An Attempt to Check the Effect of Restricted Use of Fertilizers, in Nitrate in Groundwaters, IAH Selected Papers on Hydrogeology, ed. L. Razowska-Jaworek and A. Sadurski, A.A. Balkema, Leiden, The Netherlands, 2004, pp. 247-258.

32 A. Visser and et al., Demonstrating trend reversal of groundwater quality in relation to time of recharge determined by ${ }^{3} \mathrm{H} /{ }^{3} \mathrm{He}$, Environ. Pollut., 2007, 148(3), 797-807.

33 K. K. Gardner and R. M. Vogel, Predicting ground water nitrate concentration from land use, Ground Water, 2005, 43(3), 343-352.

34 Y. Jiang and et al., Groundwater quality and land use change in a typical karst agricultural region: a case study of Xiaojiang watershed, Yunnan, Journal of Geographical Sciences, 2006, 16(4), 405-414.

35 A. Ritter and et al., Agricultural land use and hydrology affect variability of shallow groundwater nitrate concentration in South Florida, Hydrol. Process., 2007, 21(18), 2464-2473.

36 D. J. Lapworth and et al., Pesticides in groundwater: some observations on temporal and spatial trends, Water and Environment Journal, 2006, 20(2), 55-64.

37 H. J. Di and et al., A pilot regional scale model of land use impacts on groundwater quality, Management of Environmental Quality, 2005, 16(3), 220-234.

38 M. N. Almasri and J. J. Kaluarachchi, Modular neural networks to predict the nitrate distribution in ground water using the on-ground nitrogen loading and recharge data, Environmental Modelling and Software, 2005, 20(7), 851-871.

39 M. N. Almasri and J. J. Kaluarachchi, Modeling nitrate contamination of groundwater in agricultural watersheds, J. Hydrol. (Amsterdam, Neth.), 2007, 343(3-4), 211.

40 J. C. Refsgaard and et al., Large scale modelling of groundwater contamination from nitrate leaching, J. Hydrol (Amsterdam, Neth. ), 1999, 221(3-4), 117-140.

41 B. Van der Grift and J. Griffioen, Modelling assessment of regional groundwater contamination due to historic smelter emissions of heavy metals, J. Contam. Hydrol., 2008, 96(1-4), 48-68.

42 J. Grath, et al., The EU Water Framework Directive: Statistical aspects of the identification of groundwater pollution trends, and aggregation of monitoring results. Final Report, 41.046/01-IV1/00 and GZ 16 2500/2-I/6/00, Austrian Federal Ministry of Agriculture and Forestry, Environment and Water Management and European Commission, Vienna, 2001.

43 P. Quevauviller, Groundwater monitoring in the context of EU legislation: reality and integration needs, J. Environ. Monit., 2005, $7(2), 89$.

44 P. Quevauviller and et al., Science-policy integration needs in support of the implementation of the EU Water Framework Directive, Environ. Sci. Policy, 2005, 8(3), 203.

$45 \mathrm{~J}$. Grath and et al., Report on EU guidance on groundwater monitoring developed under the common implementation strategy of the water framework directive, J. Environ. Monit., 2007, 9(11), $1162-1175$.

46 J. Harris, J. C. Loftis and R. H. Montgomery, Statistical methods for characterizing ground-water quality, Ground Water, 1987, 25(2), 185193.

47 R. M. Hirsch, J. R. Slack and R. A. Smith, Techniques of trend analysis for monthly water quality data, Water Resour. Res., 1982, 18(1), 107-121.

48 R. M. Hirsch, R. B. Alexander and R. A. Smith, Selection of methods for the detection and estimation of trends in water quality, Water Resour. Res., 1991, 27(5), 803-813.

49 J. C. Loftis, C. H. Taylor and P. L. Chapman, Multivariate tests for trend in water quality, Water Resour. Res., 1991, 27(7), 1419-1429.

$50 \mathrm{~S}$. S. Shapiro and M. B. Wilk, An analysis of variance test for normality (complete samples), Biometrika, 1965, 52, 591-611.

51 S. S. Shapiro and R. S. Francia, An approximate analysis of variance test for normality, J. Am. Stat. Assoc., 1972, 67(337), 215-216.

52 J. R. Carr, Numerical Analysis for the Geological Sciences, Prentice Hall, Englewood Cliffs, NJ, 1995, p. 592.

53 M. G. Kendall, Rank Correlation Methods, Charles Griffin \& Company, London, 1948.

54 H. B. Mann, Nonparametric tests against trend, Econimetrica, 1945, 13, 245-259.
55 D. R. Helsel and R. M. Hirsch, Statistical methods in water resources, Studies in Environmental Science, Elsevier, Amsterdam, The Netherlands, 3rd edn, 1995, vol. 49, p. 529.

56 S. Yue, P. Pilon and G. Cavadias, Power of the Mann-Kendall and Spearman's rho tests for detecting monotonic trends in hydrological series, J. Hydrol. (Amsterdam, Neth. ), 2002, 259(1-4), 254-271.

$57 \mathrm{P}$. Schlosser and et al., Tritium $/{ }^{3} \mathrm{He}$ Dating of Shallow Groundwater, Earth Planet. Sci. Lett., 1988, 89(3-4), 353-362.

58 E. Busenberg and L. N. Plummer, Use of chlorofluorocarbons $\left(\mathrm{CCl}_{3} \mathrm{~F}\right.$ and $\mathrm{CCl}_{2} \mathrm{~F}_{2}$ ) as hydrologic tracers and age-dating tools: the alluvium and terrace system of Central Oklahoma, Water Resour. Res., 1992, 28(9), 2257-2283.

59 E. Busenberg and L. N. Plummer, Dating young groundwater with sulfur hexafluoride: natural and anthropogenic sources of sulfur hexafluoride, Water Resour. Res., 2000, 36(10), 3011-3030.

60 J. L. Pinault, H. Pauwels and C. Cann, Inverse modeling of the hydrological and the hydrochemical behavior of hydrosystems: application to nitrate transport and denitrification, Water Resour. Res., 2001, 37(8), 2179.

61 J. L. Pinault, Manuel utilisateur de TEMPO: logiciel de traitement et de modélisation des séries temporelles en hydrogéologie et en hydrogéochemie, Projet Modhydro. Rap. BRGMIRP-51459, BRGM, Orleans, 2001, p. 221.

62 H. P. Broers, Strategies for regional groundwater quality monitoring, in $\mathrm{PhD}$ thesis. Fysische geografie, Utrecht University, Utrecht, 2002, p. 231.

63 H. P. Broers, The spatial distribution of groundwater age for different geohydrological situations in the Netherlands: implications for groundwater quality monitoring at the regional scale, J. Hydrol (Amsterdam, Neth.), 2004, 299(1-2), 84-106.

64 A. Dassargues and A. Monjoie, The Chalk in Belgium, in The Hydrogeology of the Chalk of North-West Europe, ed. R. A. Downing, M. Price and G. P. Jones, Oxford Science Publ., Oxford, 1993, pp. 153-269.

65 C. Mouvet, et al., PEGASE. Pesticides in European Groundwaters: detailed study of representative aquifers and simulation of possible evolution scenarios, in Final Report of the European Project \#EVK1-CT1990-00028. BRGM/RP-52897-FR, ed. I. G. Dubus and C. Mouvet, 2004.

66 J. L. Pinault and I. G. Dubus, Stationary and non-stationary autoregressive processes with external inputs for predicting trends in water quality, J. Contam. Hydrol., 2008, 100(1-2), 22-29.

67 N. Baran, C. Mouvet and P. Négrel, Hydrodynamic and geochemical constraints on pesticide concentrations in the groundwater of an agricultural catchment (Brévilles, France), Environ. Pollut., 2007, 148(3), 729-738.

68 F. Steinman, Beobachtung der Grundwasserbeschaffenheit in Schleswig-Holstein: Trendmessnetz 1995-2000, Landesamt für Natur und Umwelt des Landes Schleswig-Holstein, Flintbek, Germany, 2002, p. 54.

69 A. Visser, H. P. Broers and M. F. P. Bierkens, Dating degassed groundwater with ${ }^{3} \mathrm{H} /{ }^{3} \mathrm{He}$, Water Resour. Res., 2007, 43(10), WR10434.

70 A. Visser and et al., Degassing of ${ }^{3} \mathrm{H} /{ }^{3} \mathrm{He}, \mathrm{CFCs}$ and $\mathrm{SF}_{6}$ by denitrification: measurements and two-phase transport simulations, J. Contam. Hydrol., 2009, 103(3-4), 206-218.

71 S. Roulier and et al., Controls on atrazine leaching through a soilunsaturated fractured limestone sequence at Brevilles, France, J. Contam. Hydrol., 2006, 84(1-2), 81-105.

72 A. Gutierrez and N. Baran, Long-term transfer of diffuse pollution at catchment scale: respective roles of soil, and the unsaturated and saturated zones (Brévilles, France), J. Hydrol. (Amsterdam, Neth.), 2009, 369(3-4), 381-391.

73 J. C. Vogel, Investigation of Groundwater Flow with Radiocarbon, in IAEA Symposium on Isotopes in Hydrology, 14-18 November 1966, IAEA, Vienna, Austria, 1967.

74 A. W. Harbaugh, et al., MODFLOW-2000, the U.S. Geological Survey Modular Ground-Water Model-User Guide to Modularization Concepts and the Ground-Water Flow Process. USGS Open-File Report 00-92, 2000, p. 121.

75 C. Zheng and P. P. Wang, MT3DMS: A Modular Three-Dimensional Multispecies Transport Model for Simulation of Advection, Dispersion, and Chemical Reactions of Contaminants in Groundwater Systems. Documentation and User's Guide, Department of Geological Sciences, University of Alabama, Alabama, 1999, p. 220. 
76 B. Van der Grift and C. G. E. M. Van Beek, Hardness of Abstracted Groundwater: Indicative Predictions (in Dutch), Kiwa, Nieuwegein, the Netherlands, 1996.

77 J. Šimůnek, M. Šejna and M. T. Van Genuchten, The Hydrus-1D Software Package for Simulating the One-Dimensional Movement of Water, Heat and Multiple Solutes in Variable-Saturated Media, Version 2, U.S. Salinity Laboratory, Riverside, CA, USA, 1998.

78 G. Carabin and A. Dassargues, Modeling groundwater with ocean and river Interaction, Water Resour. Res., 1999, 35(8), 2347-2358.

79 P. Orban, Solute Transport Modelling at the Groundwater Body Scale: Nitrate Trends Assessment in the Geer basin (Belgium), $\mathrm{PhD}$ Thesis, 2009, Faculty of Applied Sciences, University of Liège, Liège, p. 219

$80 \mathrm{~S}$. Brouyère and et al., The hybrid finite element mixing cell method: a new flexible method for modelling mine ground water problems, Mine Water and the Environment, 2009, 28(2), 102-114.

81 N. J. Jarvis, The MACRO Model (version 3.1). Technical Description and Sample Simulations, Reports and Dissertations 19, Department of Soil Sciences, Swedish University of Agricultural Sciences, Uppsala, Sweden, 1994.

82 D. Thiéry, Logiciel MARTHE-Modélisation d'Aquifére avec maillage Rectangulaire, Transport et HydrodynamiquE, version 4.3. $B R G M$ report $R 38210$, BRGM, Orleans, France, 1990, p. 330.
83 EU, Common Implementation Strategy for the Water Framework Directive (2000/60/EC), Guidance Document No. 15, Guidance on Groundwater Monitoring. Technical Report-002-2007, Office for Official Publications of the European Communities, Luxembourg, 2007, p. 54.

84 A. J. Tesoriero and et al., Linking ground-water age and chemistry data along flow paths: implications for trends and transformations of nitrate and pesticides, J. Contam. Hydrol., 2007, 94(1-2), 139.

85 K. R. Burow, J. L. Shelton and N. M. Dubrovsky, Regional nitrate and pesticide trends in ground water in the eastern San Joaquin Valley, California, J. Environ. Qual., 2008, 37(S5), 249-263.

86 D. A. Saad, Agriculture-related trends in groundwater quality of the glacial deposits aquifer, central Wisconsin, J. Environ. Qual., 2008, 37(S5), 209-225.

87 M. G. Rupert, Decadal-scale changes of nitrate in ground water of the United States, 1988-2004, J. Environ. Qual., 2008, 37(S5), 240-248.

88 L. M. Debrewer, S. W. Ator and J. M. Denver, Temporal trends in nitrate and selected pesticides in mid-atlantic ground water, J Environ. Qual., 2008, 37(S5), 296-308.

89 H. Behrendt, et al., Nutrient Emissions into River Basins of Germany on the Basis of a Harmonised Procedure, Umweltbundesamt, Berlin, Germany, 2003. 